\title{
Effect of Some Environmental Factors on the Growth of Azospirillum Species Isolated from Saline Soils of Satkhira District, Bangladesh
}

\author{
M Motiur Rahman ${ }^{1}$, S Mubassara ${ }^{1}$, Sirajul Hoque ${ }^{2}$ and Zahed UM Khan ${ }^{1 *}$ \\ ${ }^{1}$ Department of Botany, Jahangirnagar University, Savar, Dhaka 1342, Bangladesh, ${ }^{2}$ Department of Soil, Water \& Environment, University of Dhaka, \\ Dhaka 1000, Bangladesh
}

[Received 19 September 2006; Accepted 07 October 2006]

\begin{abstract}
Twelve isolates of Azospirillum, recovered and identified from non-rhizosphere soil, rhizosphere soil of Cynodon dactylon and the roots of the same plant, were collected from five different locations of saline area in the district Satkhira, Bangladesh. The isolates were belonged to Azospirillum lipoferum, A. brasilense, A. halopraeferans and A. amazonense. All isolates, except MR-5, preferred neutral to alkaline condition for their optimal growth. Three isolates (MR-3, MR-4 and MR-8) showed maximum growth at $41^{\circ} \mathrm{C}$, while the others grew best at temperature between $35^{\circ}$ and $37^{\circ} \mathrm{C}$. The optimal $\mathrm{NaCl}$ concentration for the growth was found to be $3 \%$ for 5 isolates (MR-1, MR-3, MR-4, MR-8 and MR-11) and 5\% for the rest 7 isolates (MR-5, MR-6, MR-7, MR-13, MR-14, MR-15 and MR-16). All isolates were true halophilic since they did not show grow in absence of salinity, and all of them were also fungicide (Perfeckthion and Indofil M-45) tolerants to some extent.
\end{abstract}

Keywords: Azospirillum, Growth characteristics, Halophilic, Tolerance to fungicide

\section{Introduction}

Microbial colonization on plant roots is affected by biotic and abiotic factors such as root exudates, competition, inorganic nutrients, soil $\mathrm{pH}$, temperature, etc. Among the agriculturally important abiotic stresses, soil salinity, alkalinity, drought and heat rank as the most detrimental and cause loss of crop productivity all over the world ${ }^{1}$. The investigation of their effects on the rhizosphere microflora may help to get a better insight into the dynamics of microbial populations in the rhizosphere.

Azospirillum species are free-living $\mathrm{N}_{2}$-fixing bacteria that live in close association with roots of cereals and other grasses and are able to promote plant growth and yields in many crops of agronomic importance ${ }^{2}$. It is assumed that the bacteria affect plant growth mainly by the production of plant growth promoting substances, which leads to an improvement in root development and an increase in the rate of water and mineral uptake ${ }^{3}$. Azospirillum species support plant growth indirectly by improving growth-restricting conditions either via production of antagonistic substances or by inducing resistance against plant pathogens ${ }^{4}$. Since associative interactions of plants and microorganisms must have come into existence as a result of coevolution, the use of this group as bio-inoculants must be preadapted, so that it fits into a long-term sustainable agricultural system. Azospirillum have been suggested as an alternative or supplement to chemical fertilization ${ }^{5}$.

The agricultural land use in the coastal areas is very poor. In the virtual absence of any tested technology suited to the coastal conditions, the farmers in most of the coastal areas rely on the age-old traditional methods of agriculture. There, however, exists scope of improvement of the situation. The nitrogen status of these soils is poor and the most appropriate solution to this situation is to exploitation of biological nitrogen fixation to supply nitrogen from the renewable source to the crops. To develop inoculants of Azospirillum for the crops of saline ecosystem in Bangladesh, isolation and screening of efficient isolates of this organism from saline soils of this country are most necessary. A few works on the distribution and $\mathrm{N}_{2}$-fixing potential of Azospirillum of normal agricultural soils have been done ${ }^{6-7}$. However, no systematic and comprehensive study has so far been conducted in Bangladesh in order to screen the efficient indigenous Azospirillum for the use as biofertilizer for crop production in saline soil. In this paper the in vitro growth of Azospirillum isolated from the saline area of Bangladesh has been reported.

\section{Materials and Methods}

Isolated and selected isolates of Azospirillum from saline soils of Bangladesh were characterized and identified according to Krieg and Döbereiner ${ }^{8}$. The growth of each isolate was determined in terms of optical density at $600 \mathrm{~nm}$ of the 72-h-old culture in $10 \mathrm{ml}$ bromothymol blue-free nitrogen containing broth ${ }^{8}$ under various temperatures, $\mathrm{pH}$ values and concentrations of $\mathrm{NaCl}$ and fungicides. To study the effect of temperatures, $\mathrm{NaCl}$, and fungicides (Perfeckthion and Indofil M-45) on growth of

*Corresponding author:

Dr. Zahed UM Khan, Professor, Department of Botany, Jahangirnagar University, Savar, Dhaka 1342, Bangladesh

Tel (Office): (02) 770878-85/1453; Tel (Home): (02) 9005732; Cell: 0171 6664432; E-mail: zahed04@proshikanet.com 
Azospirillum, malic acid was used as the carbon source in the bromothymol blue-free nitrogen containing broth of neutral $\mathrm{pH}$. However, for examining the effect of various $\mathrm{pH}$ values on the growth of Azospirillum, malate was replaced by galactose (0.5\%) in the bromothymol blue-free nitrogen containing broth to avoid changes in $\mathrm{pH}$ by the utilization of malate ${ }^{9}$. Statistical analysis was done for the results of each experiment.

\section{Results and Discussion}

A total of 12 Azospirillum isolates recovered from saline soils were selected for this study, which belonged to 4 different species of Azospirillum. Isolates MR-1, MR-11, MR-14, MR-15 and MR-16 belonged to the species Azospirillum lipoferum, isolates MR-6, MR-7 and MR-13 belonged to Azospirillum brasilense, isolates MR-3, MR-4 and MR-8 belonged to Azospirillum halopraeferans, and only isolate MR- 5 belonged to Azospirillum amazonense. The isolates MR-1, MR-3, MR-4, MR-7, MR-8 and MR-13 showed optimum growth at $\mathrm{pH} 8.0$ and the isolates MR-6,
MR-11, MR-14, MR-15 and MR-16 showed optimum growth at pH 7.0 (Table 1). A. amazonense (MR-5) showed optimal growth at $\mathrm{pH}$ 6.5. Döbereiner ${ }^{10}$ mentioned that the $\mathrm{pH}$ of soil and of root surface might affects the microbial equilibrium decisively. Earlier observations indicated that Azospirillum, like Azotobacter, requires near-neutral $\mathrm{pH}$ for abundant occurrence ${ }^{9}$. The optimal growth of different species of Azospirillum, viz., A. brasilense, A. lipoferum, A. amazonense, A. halopraeferans occur at $\mathrm{pH}$ range 6.0-7.8, 5.7-6.8, 5.7-6.5 and 6.8-8.0, respectively ${ }^{11}$.

Temperature is one of the most important factors that governs the physiology and growth of the living organisms. The high temperature requirements of azospirilla with growth optima between $32^{\circ}$ and $36^{\circ} \mathrm{C}$ might explain the much more generalized occurrence of these organisms in subtropical and tropical regions ${ }^{9}$. In the present study, the isolates MR-3, MR-4 and MR-8 showed maximum growth at $41^{\circ} \mathrm{C}$ and rest of the isolates showed maximum growth between $35^{\circ}$ and $37^{\circ} \mathrm{C}$ (Table 2).

Table 1. Effect of $\mathrm{pH}$ on the growth of selected isolates of Azospirillum

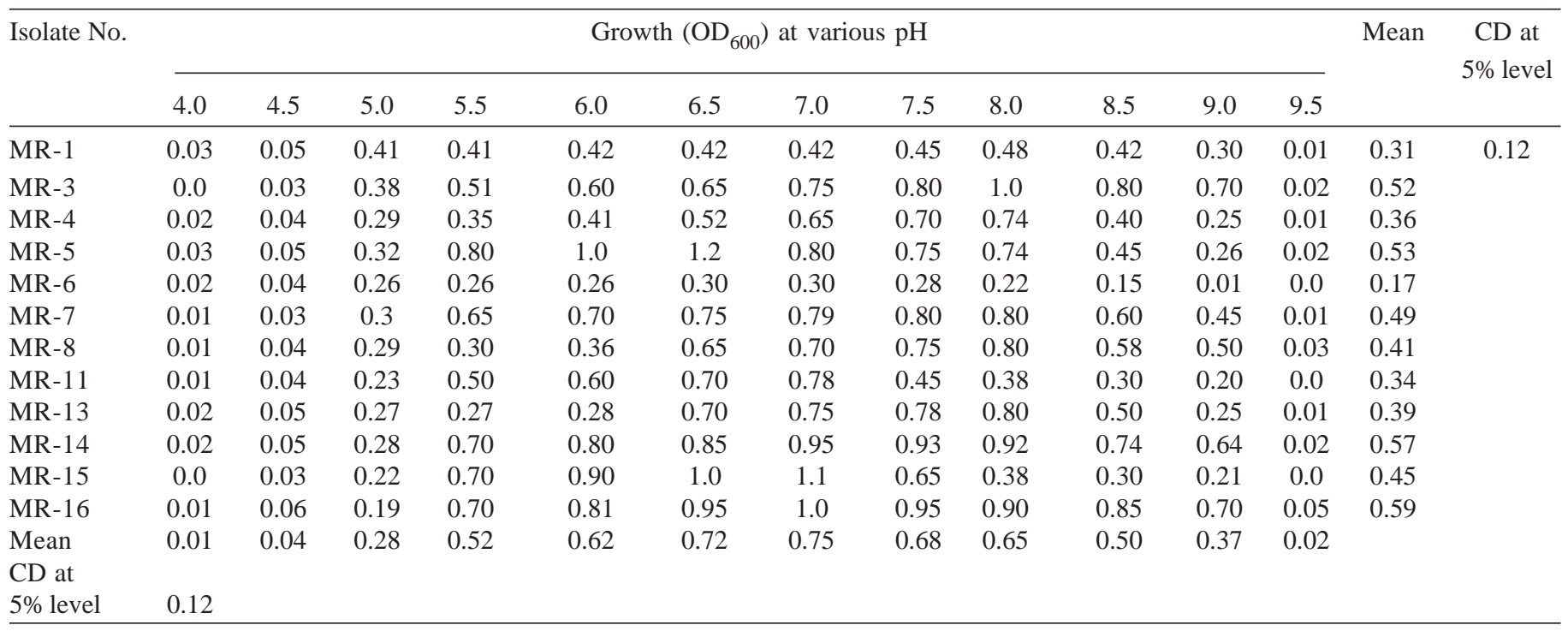

Table 2. Effect of temperature on the growth of the selected isolates of Azospirillum

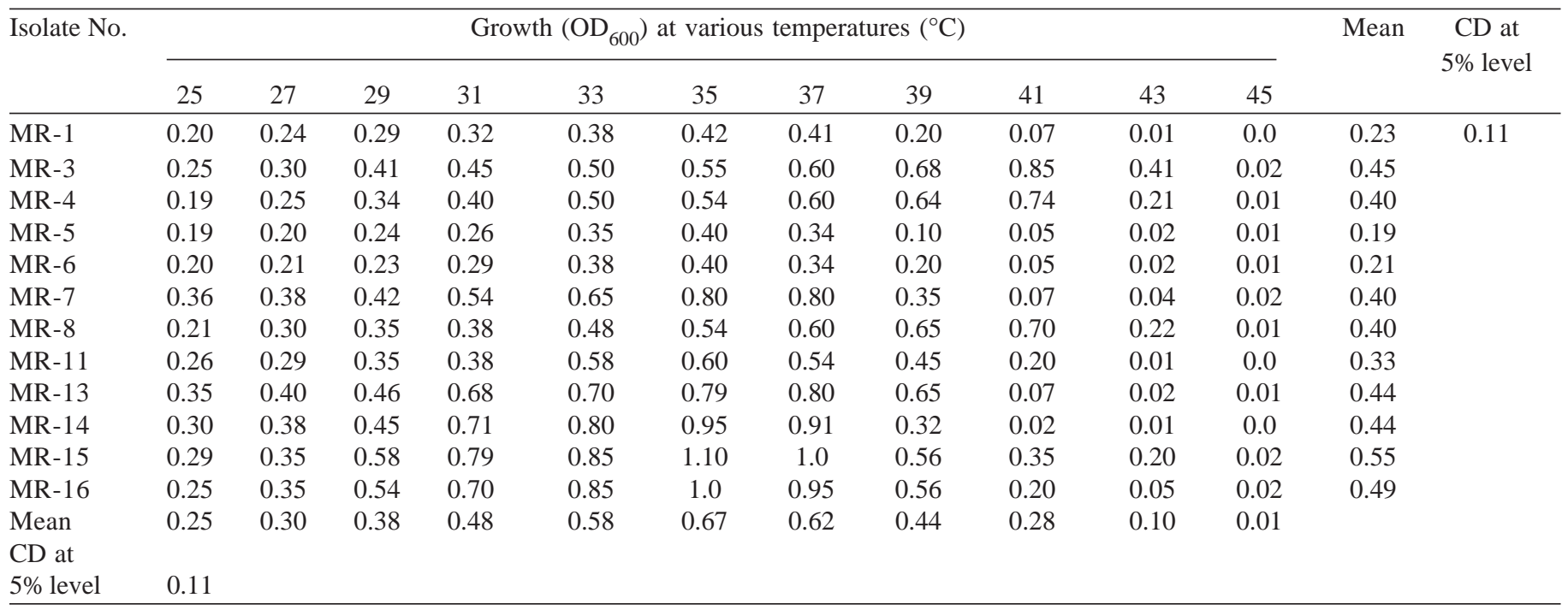


All isolates of Azospirillum preferred saline condition for proper growth (Table 3). The optimal $\mathrm{NaCl}$ concentration was found to be 3\% for the isolates MR-1, MR-3, MR-4, MR-8 and MR-11 and $5 \%$ for the isolates MR-5, MR-6, MR-7, MR-13, MR-14, MR-15 and MR-16. All isolates were unable to show recognizable growth on normal media. The results clearly confirmed that the isolates of Azospirillum were halophilic. Ravikumar et al. ${ }^{12}$ reported the isolation of $A$. brasilense from mangrove environment that showed better growth and indole acetic acid (IAA) production at $3 \% \mathrm{NaCl}$. A. halopraeferans was reported to occur in the rhizoplane of plants growing in saline soils in Brazil $^{10}$. In this study, three isolates, MR-3, MR-4 and MR-8, were identified as $A$. halopraeferans occurring in the nonrhizosphere saline soil and root of Cynodon dactylon growing in saline soil of the district Satkhira, Bangladesh. A. halopraeferans as deduced from its name seems adapted to saline soils ${ }^{10}$. Low concentrations of $\mathrm{NaCl}$ exerted an accelerating effect on the growth of bacteria ${ }^{13}$. Obligate halophiles possess specialized enzymes that become in their active configuration only at high salt concentrations ${ }^{1}$.

In this study, the significant effect of the fungicides, Perfeckthion and Indofil M-45, on the growth of the Azospirillum isolates was observed (Table 4 and 5 ). The bacteria grew better in Perfeckthion than in Indofil M-45. Two isolates MR-1 and MR-5 could tolerate up to $250 \mathrm{ppm}$ of the fungicides showing growth that was comparable to the growth in the control medium without fungicide. The MR-1 and MR-5 were belonged to A. lipoferum and A. amazonense respectively. Application of pesticides has become an integral part of present agriculture. Very little is known about their effect on non-target microorganisms. The effect of various pesticides on the growth and $\mathrm{N}_{2}$-fixation was studied using pure culture of bacteria by Wood and MacRae ${ }^{14}$ and Kulkarni et al. ${ }^{15}$.

Table 3. Effect of salinity ( $\mathrm{NaCl}$ ) on the growth of the selected isolates of Azospirillum

\begin{tabular}{|c|c|c|c|c|c|c|c|c|c|c|c|c|c|c|c|c|c|c|}
\hline \multirow[t]{2}{*}{ Isolate No. } & \multicolumn{16}{|c|}{ Growth $\left(\mathrm{OD}_{600}\right)$ at various concentrations of $\mathrm{NaCl}(\%)$} & \multirow[t]{2}{*}{ Mean } & \multirow{2}{*}{$\begin{array}{r}\text { CD at } \\
5 \% \text { level }\end{array}$} \\
\hline & 0 & 0.5 & 1.0 & 1.5 & 2.0 & 2.5 & 3.0 & 3.5 & 4.0 & 4.5 & 5.0 & 5.5 & 6.0 & 6.5 & 7.0 & 7.5 & & \\
\hline MR-1 & 0.01 & 0.17 & 0.24 & 0.29 & 0.32 & 0.35 & 0.38 & 0.31 & 0.21 & 0.2 & 0.1 & 0.02 & 0.0 & 0.0 & 0.0 & 0.0 & 0.15 & 0.12 \\
\hline MR-3 & 0.02 & 0.14 & 0.37 & 0.4 & 0.48 & 0.49 & 0.68 & 0.48 & 0.09 & 0.03 & 0.01 & 0.0 & 0.0 & 0.0 & 0.0 & 0.0 & 0.19 & \\
\hline MR-4 & 0.0 & 0.11 & 0.3 & 0.41 & 0.45 & 0.5 & 0.58 & 0.68 & 0.45 & 0.3 & 0.04 & 0.01 & 0.01 & 0.0 & 0.0 & 0.0 & 0.23 & \\
\hline MR-5 & 0.0 & 0.03 & 0.2 & 0.24 & 0.27 & 0.3 & 0.32 & 0.35 & 0.4 & 0.42 & 0.5 & 0.54 & 0.25 & 0.12 & 0.08 & 0.01 & 0.25 & \\
\hline MR-6 & 0.0 & 0.1 & 0.14 & 0.26 & 0.29 & 0.3 & 0.36 & 0.41 & 0.46 & 0.51 & 0.64 & 0.59 & 0.45 & 0.3 & 0.2 & 0.05 & 0.31 & \\
\hline MR-7 & 0.0 & 0.2 & 0.31 & 0.39 & 0.39 & 0.42 & 0.45 & 0.49 & 0.51 & 0.58 & 0.74 & 0.64 & 0.4 & 0.34 & 0.21 & 0.09 & 0.38 & \\
\hline MR-8 & 0.0 & 0.08 & 0.3 & 0.35 & 0.38 & 0.4 & 0.56 & 0.55 & 0.44 & 0.43 & 0.23 & 0.21 & 0.09 & 0.01 & 0.0 & 0.0 & 0.24 & \\
\hline MR-11 & 0.01 & 0.09 & 0.3 & 0.35 & 0.38 & 0.4 & 0.78 & 0.71 & 0.36 & 0.25 & 0.08 & 0.0 & 0.0 & 0.0 & 0.0 & 0.0 & 0.23 & \\
\hline MR-13 & 0.0 & 0.1 & 0.28 & 0.3 & 0.38 & 0.42 & 0.45 & 0.48 & 0.5 & 0.8 & 1.0 & 1.2 & 0.9 & 0.21 & 0.08 & 0.01 & 0.43 & \\
\hline MR-14 & 0.0 & 0.01 & 0.3 & 0.39 & 0.4 & 0.45 & 0.49 & 0.5 & 0.55 & 0.59 & 0.57 & 0.57 & 0.45 & 0.21 & 0.11 & 0.05 & 0.35 & \\
\hline MR-15 & 0.0 & 0.2 & 0.29 & 0.32 & 0.42 & 0.45 & 0.51 & 0.7 & 0.75 & 0.8 & 0.85 & 0.72 & 0.65 & 0.25 & 0.05 & 0.01 & 0.41 & \\
\hline MR-16 & 0.0 & 0.2 & 0.3 & 0.35 & 0.42 & 0.49 & 0.5 & 0.55 & 0.71 & 0.8 & 0.86 & 0.73 & 0.54 & 0.32 & 0.1 & 0.02 & 0.42 & \\
\hline Mean & 0.0 & 0.11 & 0.27 & 0.33 & 0.38 & 0.41 & 0.5 & 0.51 & 0.45 & 0.47 & 0.46 & 0.43 & 0.31 & 0.14 & 0.06 & 0.02 & & \\
\hline
\end{tabular}

$\mathrm{CD}$ at

5\% level 0.14

Table 4. Effect of fungicide (Perfeckthion) on the growth of the selected isolates of Azospirillum

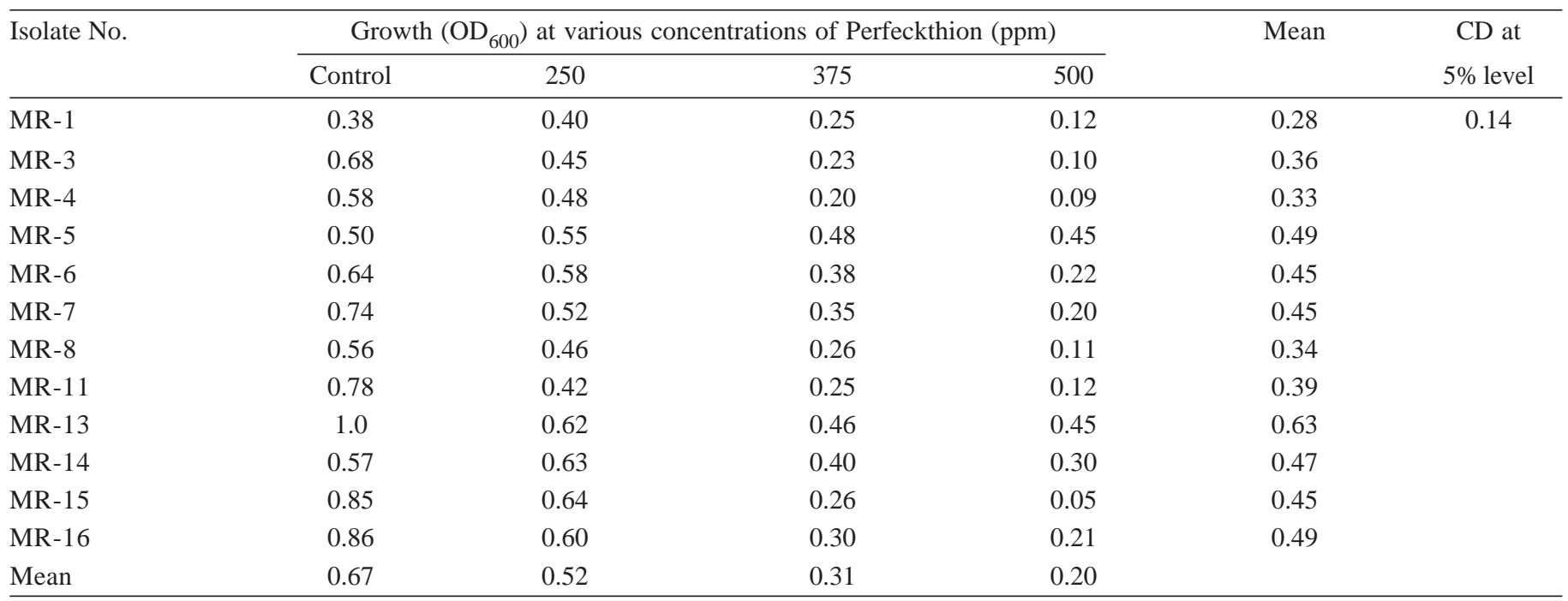


Table 5. Effect of fungicide (Indofil M-45) on the growth of the selected isolates of Azospirillum

\begin{tabular}{|c|c|c|c|c|c|c|}
\hline \multirow[t]{2}{*}{ Isolate No. } & \multicolumn{4}{|c|}{ Growth $\left(\mathrm{OD}_{600}\right)$ at various concentrations of Indofil M-45 (ppm) } & \multirow[t]{2}{*}{ Mean } & \multirow{2}{*}{$\begin{array}{c}\text { CD at } \\
5 \% \text { level }\end{array}$} \\
\hline & Control & $250 \mathrm{ppm}$ & 375 ppm & $500 \mathrm{ppm}$ & & \\
\hline MR-1 & 0.38 & 0.38 & 0.18 & 0.01 & 0.23 & 0.15 \\
\hline MR-4 & 0.58 & 0.27 & 0.17 & 0.11 & 0.28 & \\
\hline MR-5 & 0.50 & 0.35 & 0.23 & 0.14 & 0.30 & \\
\hline MR-8 & 0.56 & 0.30 & 0.21 & 0.11 & 0.29 & \\
\hline MR-11 & 0.78 & 0.39 & 0.23 & 0.12 & 0.38 & \\
\hline MR-13 & 1.0 & 0.41 & 0.29 & 0.14 & 0.46 & \\
\hline MR-14 & 0.57 & 0.44 & 0.27 & 0.13 & 0.35 & \\
\hline CD at 5\% level & 0.09 & & & & & \\
\hline
\end{tabular}

In the present investigation, variations in characteristics of the isolates of Azospirillum were observed. Statistical analysis showed that $\mathrm{pH}$, temperature, $\mathrm{NaCl}$ and pesticide influenced significantly the growth of the Azospirillum isolates. It was evident from this work that saline soil harbours halophilic azospirilla and they could colonize in the roots of the plants growing in saline habitats. Further works are required to ascertain the potentiality of these organisms for use them as biofertilizer for improving crop yield in saline agricultural fields.

\section{References}

1. Atlas RM \& Bartha R. 1998. Microbial Ecology: Fundamentals and Application. Benjamin/Cummings Publishing Co Inc, California.

2. Marchal K \& Vanderleyden J. 2000. The "oxygen paradox" of dinitrogen-fixing bacteria. Biol Fertil Soils. 30: 363-373.

3. Bashan Y \& Holguin G. 1997. Azospirillum-plant relationships: Environmental and physiological advances (1990-1996). Can J Microbiol. 43: 103-121.

4. Tilak KVBR, Ranganayaki N, Pal KK, De R, Saxena AK, Nautiyal CS, Mittal S, Tripathi AK \& Johri BN. 2005. Diversity of plant growth and soil health supporting bacteria. Curr Sci. 89(1): 136-150.

5. Mertens T \& Hess D. 1984. Yield increases in spring wheat (Triticum aestivum) inoculated with Azospirillum lipoferum under greenhouse and field conditions of temperature regions. Plant Soil. 82: 87-99.

6. Khan ZUM, Akond MA \& Mubassara S. 2001. Population of heterotrophic bacteria and Azospirillum in wheat field soil and the nitrogen fixing potential of Azospirillum of the same soil. Bangladesh J Life Sci. 13(1-2): 1-5.
7. Mubassara S, Akond MA \& Khan ZUM. 2001. Effect of Azospirillum inoculation on the growth and yield of wheat. Bangladesh J Life Sci. 13(1-2): 119-125.

8. Krieg NR \& Döbereiner J. 1984. Genus Azospirillum. In Bergey's Manual of Systematic Bacteriology (Krieg NR \& Holt JG eds), Vol 1, pp 94-104. Williams \& Wilkins, Baltimore, Maryland.

9. Döbereiner J \& Day JM. 1976. Association symbiosis in tropical grasses: Characterization of microorganisms and dinitrogen-fixing sites. In Proceedings of the First International Symposium on Nitrogen Fixation (Newton WE \& Nyman CJ eds), Vol 2, pp 518-538. Washington State University Press, Pullman, Washington DC.

10. Döbereiner J. 1992. The genera Azospirillum and Herbaspirillum. In The Prokaryotes - A Handbook on the Biology of Bacteria: Ecophysiology, Isolation, Identification and Applications (Balows A, Truper HG, Dworkin M, Harder W \& Schleifer KH eds), $2^{\text {nd }}$ edn, Vol 3, pp 2236-2253. Springer-Verlag Inc, New York.

11. Reinhold B, Hurek T, Fendrik I, Pot B, Gillis M, Kertsers K, Thielemans D \& De J Ley. 1987. Azospirillum halopraeferans sp nov. A nitrogenfixing organism associated with roots of Kallar grass Leptochloa fusca (L) Kunth. Int J Syst Bacteriol. 37: 43-51.

12. Ravikumar S, Ramnathan G, Suba N, Jeyaseeli L \& Sukumaran M. 2002. Quantification of halophilic Azospirillum from mangroves. Indian J Marine Sci. 31(2): 157-160.

13. Salle AJ. 1974. Fundamental Principles of Bacteriology, $7^{\text {th }}$ edn. Tata McGraw-Hill Publishing Co Ltd, New Delhi.

14. Wood PA \& MacRae IC. 1974. The effect of several organophosphorus insecticides upon the acetylene reduction activity of Azotobacter vinelandii. Bull Environ Contam Toxicol. 12: 26-31.

15. Kulkarni JH, Sardeshpande JS \& Bagyaraj DJ. 1974. Effect of four soil applied insecticides on symbiosis of Rhizobium sp. with Arachis hypogea Linn. Plant Soil. 40: 169-172. 